\title{
Nonuniform Deficiency of Hexosaminidase $A$ in Tissues and Fluids of Two Unrelated Individuals
}

\author{
GEORGE H. THOMAS ${ }^{(20)}$, SRINIVASA RAGHAVAN, EDWIN H. KOLODNY, AMOS FRISCH, \\ ELIZABETH F. NEUFELD, JOHN S. O'BRIEN, LINDA W. REYNOLDS, CAROL S. MILLER, JULIE \\ SHAPIRO, HAIG H. KAZAZIAN, JR., AND RICHARD H. HELLER \\ The John F. Kennedy Institute and/or Departments of Pediatrics and Medicine, The Johns Hopkins University, \\ School of Medicine, Baltimore, Maryland [G.H.T., L.W.R., C.S.M., J.S., H.H.K.]; Eunice Kennedy Shriver Center, \\ Waltham, Massachusetts [S.R., E.H.K.]; The Genetics and Biochemistry Branch, National Institute of Arthritis, \\ Metabolism and Digestive Diseases, NIH, Bethesda, Maryland [A.F., E.F.N.]; Department of Neurosciences, School \\ of Medicine, University of California, San Diego, La Jolla, California [J.S.O'B.]; and Genetic Clinic, Greater \\ Baltimore Medical Center, Baltimore, Maryland, USA [R.H.H.]
}

\section{Summary}

Serum samples from two unrelated, clinically normal individuals lacked detectable hexosaminidase $A$ by heat inactivation and electrophoretic analysis. In contrast, 15 and $17 \%$ of the hexosaminidase in their leukocytes and 23 and $26 \%$ of the hexosaminidase of their cultured fibroblasts had the heat stability and electrophoretic properties of the $A$ form of this enzyme. An in vitro measurement of fibroblasts $\mathbf{G M}_{2}$ ganglioside- $\boldsymbol{\beta}$-galactosaminidase was in the range expected for Tay-Sachs disease (TSD) heterozygotes (2.5 and 3.1 versus a normal mean of 3.7). In contrast, fibroblasts from a patient with TSD, analyzed in an identical fashion, contained no detectable activity.

Ten days after addition of labeled $\mathrm{GM}_{2}$ ganglioside to the medium of the cultured fibroblasts, 43 and $59 \%$ of the radioactivity taken up by the cells of these patients remained as unhydrolyzed ganglioside as compared with $94 \%$ in TSD fibroblasts and $42 \%$ in control cells.

An analysis of sphingolipid composition by high performance liquid chromatography although the endogenous level of $\mathrm{GM}_{2}$ was elevated in TSD fibroblasts (0.39 nmoles/mg protein) there was no increase in the cells of these patients $(0$ and 0.12 versus control of $0.17 \mathrm{nmoles} / \mathrm{mg}$ protein).

Finally, the synthesis of hexosaminidase was examined by an electrophoretic analysis of immunoprecipitates of the enzyme precursors that had been radiolabeled by culturing fibroblasts in medium containing $\left|{ }^{3} \mathrm{H}\right|$-leucine. These studies revealed a normal pattern of biosynthesis, processing and secretion of the $\alpha$ and $\beta$ chains. The ratio of the $\alpha$ chain to the $\beta$ chain, however, was in the range expected for TSD heterozygotes.

\section{Speculation}

In all likelihood, these individuals suffer from a genetic or physiologic abnormality that results in the absence of hexosaminidase $A$ in serum and a relative preservation of activity against both $\mathrm{GM}_{2}$ ganglioside and 4 -methylumbelliferyl- $\mathrm{N}$-acetyl- $\boldsymbol{\beta}$-glucosaminide in cultured fibroblasts.

For the past 10 years there has been much effort directed towards the detection of persons who are either heterozygous or homozygous for the gene(s) responsible for TSD (8). One of the unexpected by-products of these efforts has been the discovery of a number of juveniles or adults either lacking or having greatly reduced hexosaminidase $A$ in serum. Studies on other tissues have generally shown these deficiencies to be similar in all tissues and fluids of the same subject. Moreover, while some of these patients appeared initially to be clinically normal, follow-up investigations revealed a variety of late onset or atypical forms of $\mathrm{GM}_{2}$ gangliosidosis $(3,5,7,13)$.

We present here, an analysis of the fluids and fibroblasts of two individuals that differ from the above findings. Specifically, while both of these patients had no detectable hexosaminidase $A$ in their serum and low levels in their leukocytes, their cultured skin fibroblasts had enzyme levels similar to that found in persons heterozygous for the TSD gene. Detailed biochemical analysis of the fibroblasts indicates that these two individuals differ from other persons reported as having variant or altered enzyme forms resulting in partial hexosaminidase $\mathrm{A}$ deficiencies. Moreover, to date, both lack any evidence of clinical disease.

\section{MATERIALS AND METHODS}

Cultured fibroblasts. Patient 1 is a 6-month-old, healthy male, the only child of Ashkenazi Jewish parents whose families trace their ancestry to Eastern Europe and Russia. Patient 2 is a 43 year-old woman of non-Jewish background previously described by Kelly et al. (9).

Fibroblast cultures were established from 2-3 $\mathrm{mm}$ square biopsies obtained from the forearms of the individuals included in this study. The cells were cultured and maintained in Eagle's minimum essential medium supplemented with L-glutamine, fetal calf serum and antibiotics as previously described $(11,15)$. Amniotic fluid cells of patient 1 , obtained at the 17th wk of his mother's pregnancy, were established and maintained in culture in a similar fashion.

Hexosaminidase A (4-Methylumbelliferyl- $N$-acetyl- $\beta$-D-glucosaminidase). Total and heat stable hexosaminidase ( $\mathrm{N}$-acetyl- $\beta$-glucosaminidase) activity was determined in serum samples according to the method described by Kaback (6). These activities were also determined in cultured fibroblasts ruptured by sonication in distilled water at a concentration of approximately $1 \mathrm{mg}$ protein per $\mathrm{ml}$. Prior to heat inactivation, the sonicates were diluted $1: 5(\mathrm{v} / \mathrm{v})$ in a solution of $0.6 \%$ bovine serum albumin dissolved in citratephosphate buffer, pH 4.4. Heat inactivation was carried out at $52^{\circ} \mathrm{C}$ for 0,120 and $180 \mathrm{~min}$. Fifty $\mu$ l samples were then incubated with $0.1 \mathrm{ml}$ of a $3 \mathrm{mM}$ solution of 4-methylumbelliferyl- $\mathrm{N}$-acetyl-

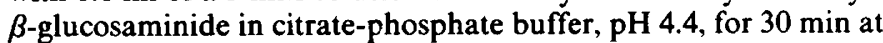
$37^{\circ} \mathrm{C}$. The reaction was terminated by the addition of $4.85 \mathrm{ml}$ of glycine-carbonate buffer, $\mathrm{pH} 10.0$, and the fluorescence determined as with the serum $(6,11)$.

The electrophoretic separation of the components of $\mathrm{N}$-acetyl$\beta$-glucosaminidase was performed on Cellogel (19) strips $(7.8 \mathrm{~cm}$ x $15 \mathrm{~cm} \times 500 \mathrm{~mm}$ ) in $0.035 \mathrm{M}$ citric acid-sodium citrate, $\mathrm{pH} 5.5$, for $2.0 \mathrm{~h}$ at $4-5 \mathrm{~mA}$ (voltage $\sim 150$ ) at room temperature according to the procedures of Rattazzi and Davidson (14). 
In vitro assay of ganglioside $G_{2}-N$-acetyl- $\beta$-D-galactosaminidase. $\mathrm{GM}_{2}$ ganglioside, labeled in the $\mathrm{N}$-acetyl-galactosaminyl moiety by oxidation with galactose oxidase and reduction with tritiated sodium borohydride, was utilized as the substrate for the direct assay of ganglioside $\mathrm{GM}_{2} \mathrm{~N}$-acetyl- $\beta$-D-galactosaminidase according to the method of O'Brien et al. (12). Fibroblast extracts were incubated with the labeled substrate in the presence of sodium taurocholate in citrate-phosphate buffer, $\mathrm{pH}$ 4.1. Following incubation, the reaction was terminated and the free labeled $\mathrm{N}$-acetyl-galactosamine determined following separation from the labeled $\mathrm{GM}_{2}$ ganglioside on a DEAE cellulose microcolumn.

In vivo assay of $G_{2} N$-acetyl- $\beta$-galactosaminidase activity. The ability of growing skin fibroblasts to cleave sphingosine labeled $\mathrm{GM}_{2}$ ganglioside was determined by the method of Kolodny et al. (10). Five $\mathrm{ml}$ of MEM containing $10 \%$ fetal calf serum, $2 \mathrm{mM}$ glutamine, Pen-Strep (100 units per $\mathrm{ml}$ ) and sphingosine-labeled $\mathrm{GM}_{2}(16 \mu \mathrm{M}$; specific activity, $21,000 \mathrm{cpm} / \mathrm{nmole})$ was added to a confluent cell culture. After 10 days in culture, the cells were washed free of radioactivity with PBS, harvested by trypsinization and extracted with chloroform-methanol $(2: 1)$. The chloroformmethanol extract was partitioned according to the Folch procedure (2). By this technique, the labeled, unhydrolyzed ganglioside was recovered in the aqueous (upper) phase while the products of the metabolized ganglioside were found in the organic (lower) phase.

Analysis of $\beta$-hexosaminidase synthesis. The biosynthesis and processing of the subunits ( $\alpha$ and $\beta$ chains) of $\beta$-hexosaminidase was followed by the method of Hasilik and Neufeld (4). Intact fibroblasts were cultured in medium supplemented with $\left[{ }^{3} \mathrm{H}\right]$ leucine for $3 \mathrm{~h}, 9 \mathrm{~h}$ or $3 \mathrm{~h}$ followed by a chase of $20 \mathrm{~h}$ and the media and cells were immunoprecipitated with antiserum raised against placental $\beta$-hexosaminidase $A$. The immunoprecipitates were subjected to polyacrylamide gel electrophoresis in the presence of $\mathrm{NaDod} \mathrm{SO}_{4}$ and the radioactive bands were visualized by fluorography.

Analysis of sphingolipids. The endogenous ganglioside and neutral sphingolipid composition of the cultured fibroblasts were determined by high performance liquid chromatography $(1,16)$.

\section{RESULTS}

Serum samples from individual 1 and individual 2 lacked hexosaminidase $A$. The absence of this enzyme was demonstrated

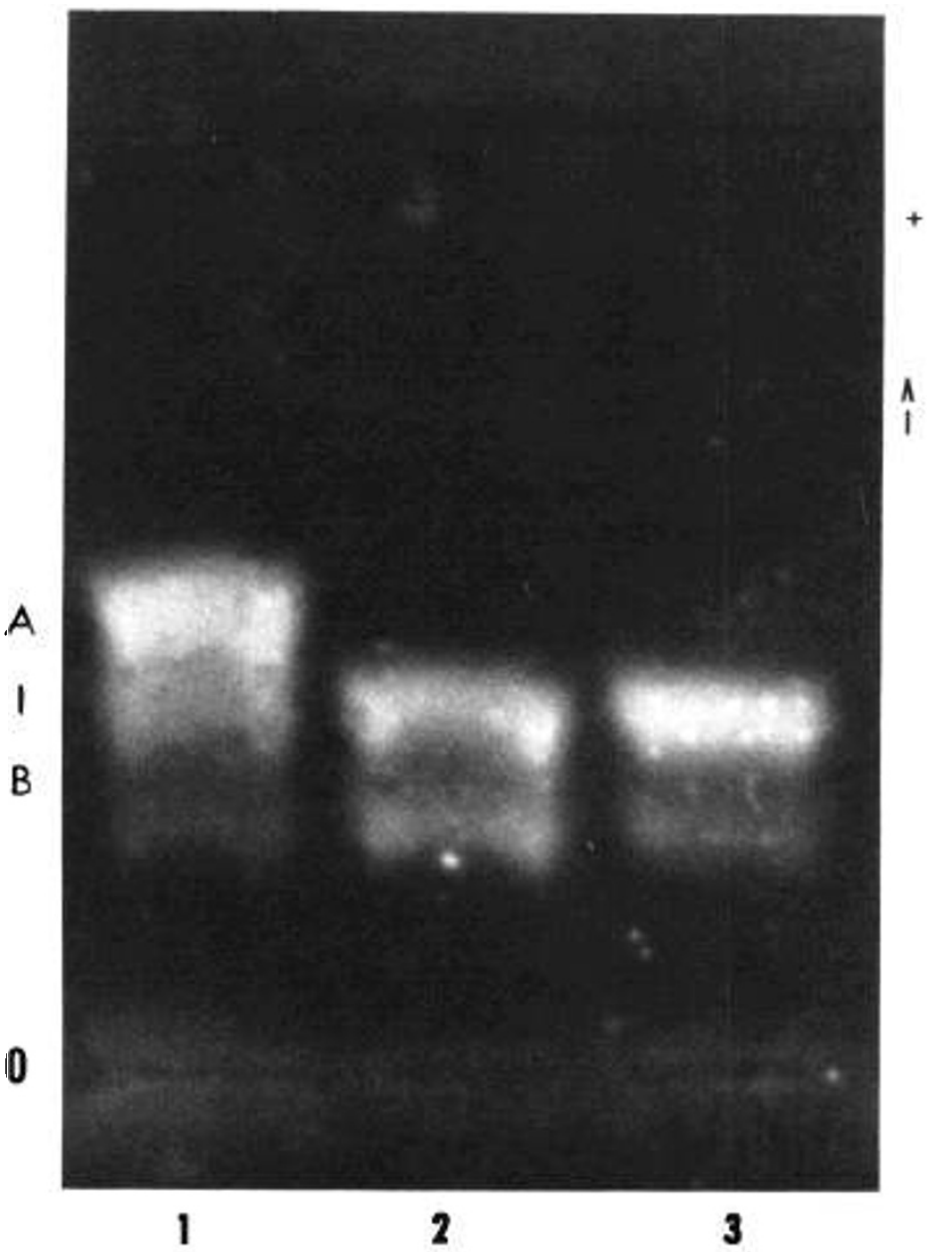

Fig. 1. Electrophoresis of hexosaminidase in serum (approximately 10 $\mu$ l per sample). Lane 1, normal; Lane 2, TSD patient; and Lane 3, Patient 1. Abbreviations and symbols: $A$, hexosaminidase $A$; $I$, intermediate hexosaminidase; B, hexosaminidase B; $O$, origin; + , polarity, and $\uparrow$, direction of migration.

Table 1. Total and heat labile hexosaminidase in serum, white blood cells and fibroblasts ${ }^{1}$

\begin{tabular}{|c|c|c|c|c|c|c|}
\hline & \multicolumn{2}{|c|}{ Serum } & \multicolumn{2}{|c|}{ White Blood Cells } & \multicolumn{2}{|c|}{ Fibroblasts } \\
\hline & T.A. ${ }^{2}$ & $\% \mathrm{~A}^{3}$ & T.A. & $\% \mathrm{~A}$ & T.A. & $\% \mathrm{~A}$ \\
\hline \multicolumn{7}{|l|}{ Family 1} \\
\hline Patient 1 & 963 & 1 & 1039 & 17 & 3108 & 26 \\
\hline Mother & 806 & 38 & 984 & 44 & 2238 & 34 \\
\hline Father & 651 & 41 & 1145 & 47 & 2013 & 39 \\
\hline \multicolumn{7}{|l|}{ Family 2} \\
\hline Patient 2 & 710 & 7 & 420 & 15 & 3032 & 23 \\
\hline Mother & 705 & 38 & 535 & 51 & N.D. ${ }^{4}$ & N.D. \\
\hline Son 1 & 805 & 39 & 475 & 47 & N.D. & N.D. \\
\hline Son 2 & 765 & 38 & 395 & 57 & N.D. & N.D. \\
\hline Son 3 & 565 & 28 & 485 & 48 & N.D. & N.D. \\
\hline \multicolumn{7}{|l|}{ TSD Carriers } \\
\hline Mean & 733 & 37 & 1210 & 45 & 2411 & 35 \\
\hline Range & $470-1151$ & $29-43$ & $665-2491$ & $41-49$ & $2069-2787$ & $27-47$ \\
\hline \multicolumn{7}{|c|}{ TSD Patients } \\
\hline Mean & 883 & 1.5 & N.D. & N.D. & 4967 & 5.5 \\
\hline Range & $509-1484$ & $0-4$ & & & $3710-6443$ & $4.5-6$ \\
\hline \multicolumn{7}{|l|}{ Control } \\
\hline Mean & 876 & 56 & 1439 & 63 & 3275 & 56 \\
\hline Range & $700-1164$ & $51-65$ & $837-2369$ & $59-67$ & $1966-4468$ & $49-65$ \\
\hline
\end{tabular}

\footnotetext{
' Values expressed as nmoles of 4-methylumbelliferyl- $\mathrm{N}$-acetyl- $\beta$-glucosaminide cleaved per $\mathrm{h}$ per $\mathrm{ml}$ or $\mathrm{mg}$ protein.

${ }^{2}$ T.A. $=$ total hexosaminidase.

${ }^{3} \% \mathrm{~A}=\%$ of hexodaminidase inactived in $3 \mathrm{~h}$ at $52^{\circ} \mathrm{C}$.

${ }^{4} \mathrm{~N} . \mathrm{D} .=$ not determined.
} 


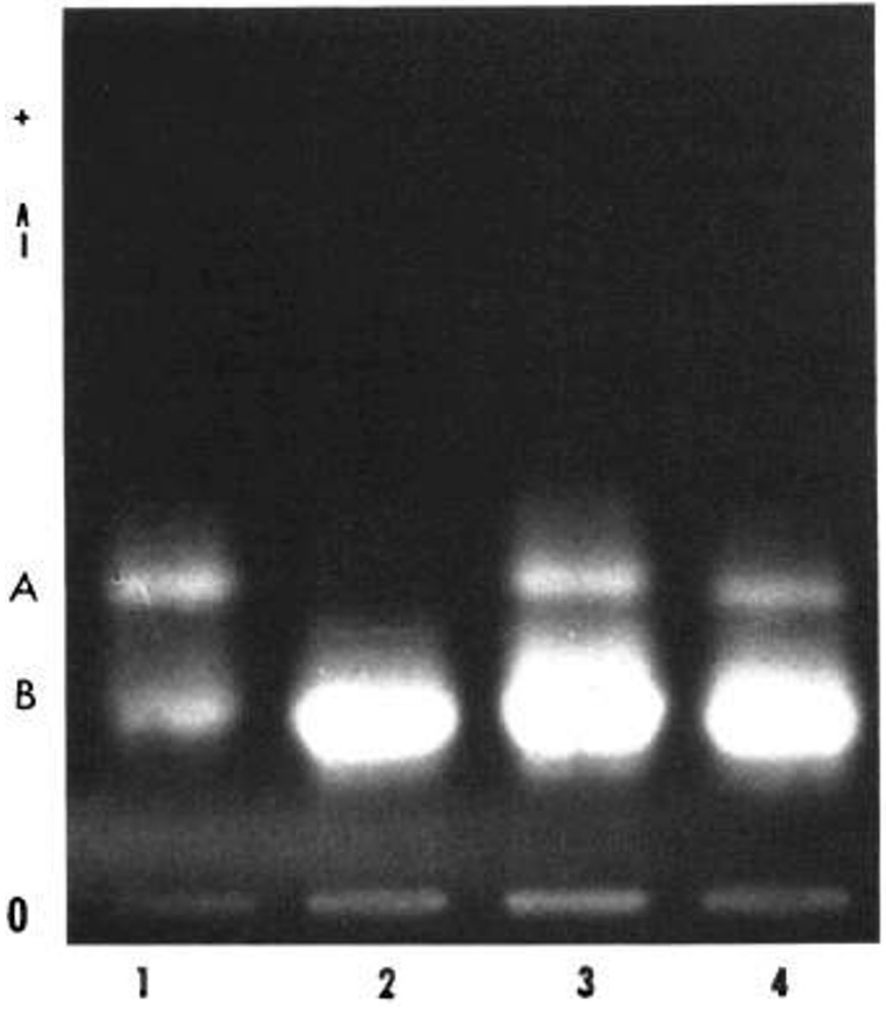

Fig. 2. Electrophoresis of hexosaminidase in cultured skin fibroblasts (approximately 5-10 $\mu \mathrm{g}$ soluble protein per sample). Lane 1, normal; Lane 2, TSD patient; Lane 3, Patient 1; and Lane 4, Patient 2. See Figure 1 for abbreviations.

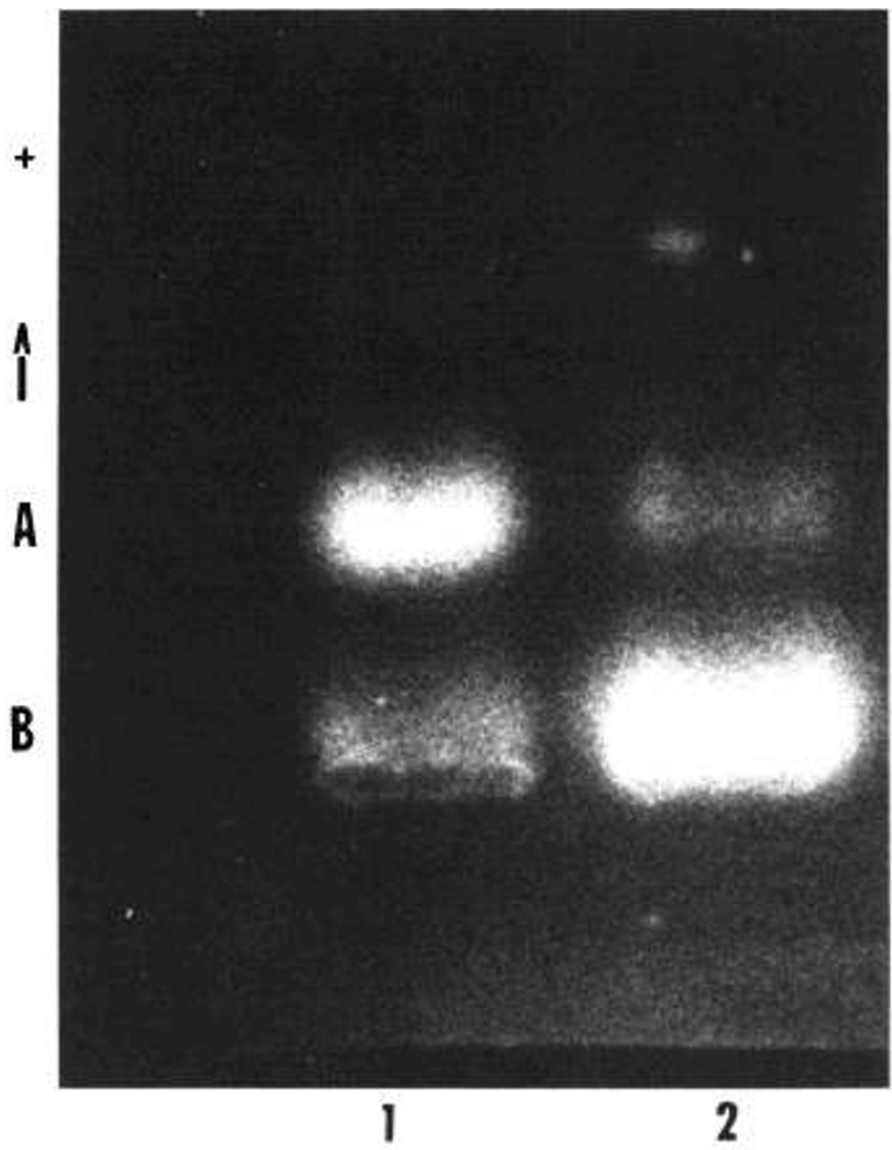

Fig. 3. Electrophoresis of hexosaminidase in white blood cells. Lane I, normal; and Lane 2, Patient 1. by both heat stability studies (Table 1) and electrophoretic analysis (Fig. 1) of serum samples obtained on several different occasions (see reference 9 for photograph of the electrophoretic results of patient 2). Similar findings were found in serum obtained from a cord blood sample at the time of the birth of individual 1 . Studies on various related family members yielded results indistinguishable from those of carriers for the classical TSD gene (Table 1).

In contrast, $23-26 \%$ of the hexosaminidase activity in cultured fibroblasts and $15-17 \%$ of the hexosaminidase in white blood cells from both of these individuals had the heat stability and electrophoretic properties characteristic of the $A$ form of this enzyme

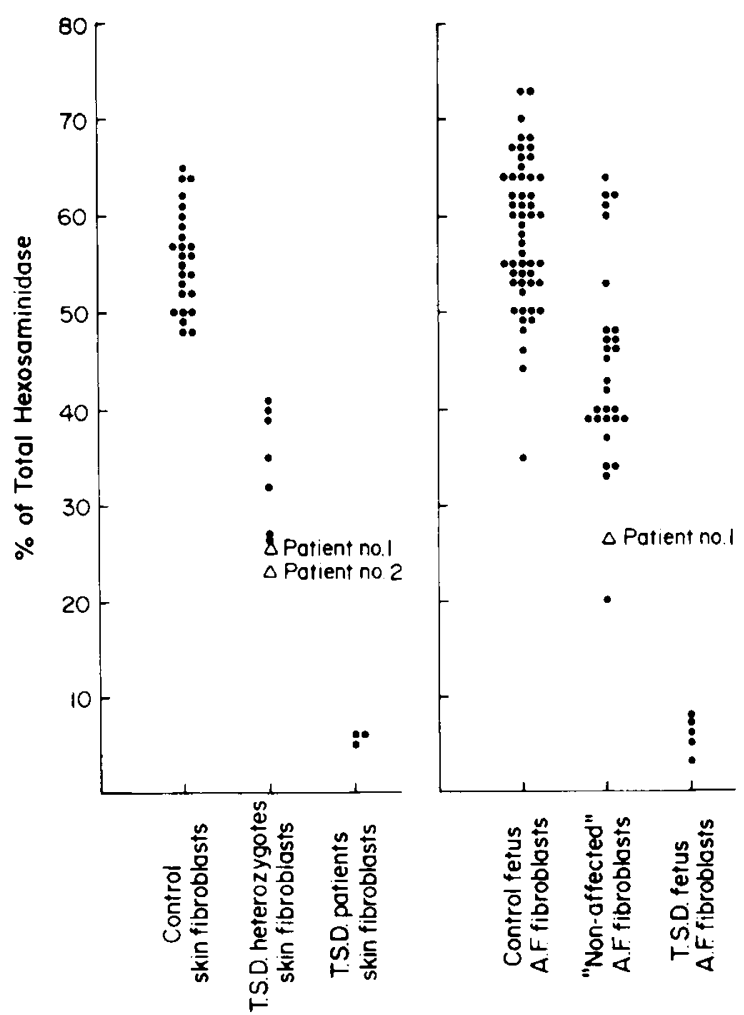

Fig. 4. Hexosaminidase $\mathbf{A}$ in sonicates of cultured amniotic fluid cells and cultured skin fibroblasts.

Table 2. $G M_{2}-N$-acetyl- $\beta$-galactosaminidase activity in fibroblasts

\begin{tabular}{|c|c|}
\hline Individual & Units $^{1}$ \\
\hline Patient 1 & 3.1 \\
\hline Patient 2 & 2.5 \\
\hline TSD patient ${ }^{2}$ & 0 \\
\hline Normal $^{2}$ & 5.4 \\
\hline Normal range & $2.5-7.0$ \\
\hline
\end{tabular}

' nmoles $\mathrm{GM}_{2}-\beta$-N-acetylgalactosamine hydrolyzed per $\mathrm{mg}$ protein per h at $37^{\circ} \mathrm{C}$.

${ }^{2}$ Analyzed simultaneously during same experiment.

Table 3. Distribution of radioactivity after Folch-partitioning of chloroform-methanol (2:1) extracts of fibroblasts fed labeled sphingosine-labeled $G_{2}$

\begin{tabular}{lcccc}
\hline Cell line & Total $^{\prime}$ & Lower phase $^{1}$ & Upper phase $^{1} \%$ in upper phase \\
\hline Patient 1 & 133,707 & 75,787 & 57,920 & 43 \\
Patient 2 & 234,597 & 96,483 & 138,114 & 59 \\
Tay-Sachs & 201,848 & 12,997 & 188,851 & 94 \\
Control & 131,158 & 76,205 & 54,953 & 42 \\
\hline
\end{tabular}

' Values are the average of cell lines run in triplicate and are expressed as $\mathrm{cpm} / \mathrm{mg}$ protein. 
(See Table 1 and Fig. 2 and 3). Fibroblasts cultured from amniotic fluid obtained during the 17 th wk of pregnancy of the mother of patient 1 yielded similar results (Fig. 4). Direct evidence that this was hexosaminidase $A$ was provided by an in vitro measurement of $\mathrm{GM}_{2}-\mathrm{N}$-acetyl- $\beta$-galactosaminidase. As shown in Table 2 skin fibroblasts from these variants had activities at the lower end of the normal range. In contrast, fibroblasts from a known TSD

Table 4. Endogenous monosialo ganglioside and sphingolipid composition of cultured fibroblasts ${ }^{1}$

\begin{tabular}{lccccccc}
\hline Cell line & $\mathrm{GM}_{3}$ & $\mathrm{GM}_{2}$ & $\begin{array}{c}\text { Ceram- } \\
\text { ide }\end{array}$ & $\mathrm{CMH}^{2}$ & $\mathrm{CDH}^{3}$ & $\mathrm{CTH}^{4}$ & $\begin{array}{c}\text { Globo- } \\
\text { side }\end{array}$ \\
\hline Patient 1 & 0.54 & N.D. $^{5}$ & 0.54 & 0.47 & 0.10 & 0.21 & 0.13 \\
Patient 2 & 0.48 & 0.12 & 0.33 & 0.46 & 0.06 & 0.31 & 0.12 \\
Tay-Sachs & 0.88 & 0.39 & 1.14 & 0.85 & 0.08 & 0.28 & 0.11 \\
Control 2 & 0.79 & 0.17 & 0.31 & 0.40 & 0.04 & 0.29 & 0.13 \\
\hline
\end{tabular}

' Values expressed as nanomoles per mg protein.

${ }^{2} \mathrm{CMH}$, ceramide monohexoside.

${ }^{3} \mathrm{CDH}$, ceramide dihexoside.

${ }^{4} \mathrm{CTH}$, ceramide trihexoside.

${ }^{5}$ N.D., not demonstrable. patient lacked the ability to cleave the $\mathrm{GM}_{2}-\mathrm{N}$-acetylgalactosaminide.

An in vivo measurement of the ability of these fibroblasts to hydrolyze $\mathrm{GM}_{2}$ ganglioside was performed by culturing intact cells with sphingosine-labeled ganglioside. After 10 days in culture, 43,59 and $42 \%$ of the label taken up by cells from individuals 1 and 2 and a control was present as unhydrolyzed ganglioside (Table 3 ). In contrast, $94 \%$ of the label remained as unhydrolyzed ganglioside in fibroblasts from a known TSD patient.

As shown in Table 4, the TSD fibroblasts were also characterized by an increase in the concentration of endogenous $\mathrm{GM}_{2}$ when compared to the fibroblasts from individuals 1,2 and a control.' In contrast, levels of other sphingolipids were similar in the fibroblasts from the TSD patients, patients 1 and 2 and the control (Table 4).

The ability of these fibroblasts to synthesize, process and excrete the $\alpha$ and $\beta$ chains of hexosaminidase was examined by the method of Hasilik and Neufeld (4). Intact fibroblasts were cultured in the presence of media containing $\left[{ }^{3} \mathrm{H}\right]$-leucine for $3 \mathrm{~h}, 9 \mathrm{~h}$ or 3 $\mathrm{h}$ followed by a $20 \mathrm{~h}$ chase media lacking labeled leucine. As shown in Figure 5, fibroblasts from individuals 1 and 2 as well as the control, contained several radioactive polypeptides that were

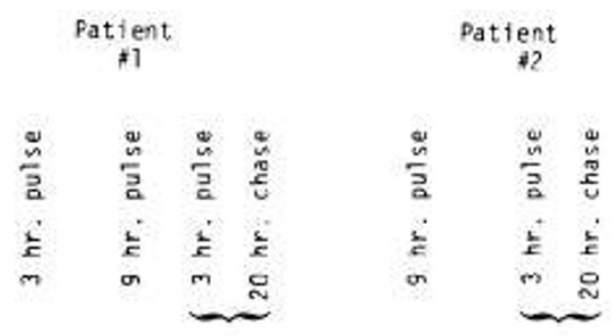

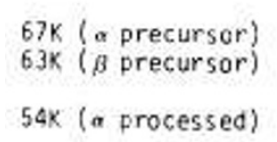

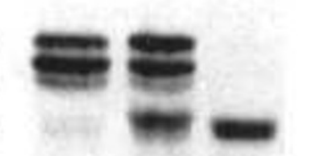

$29 K$ ( $\beta$ processed)
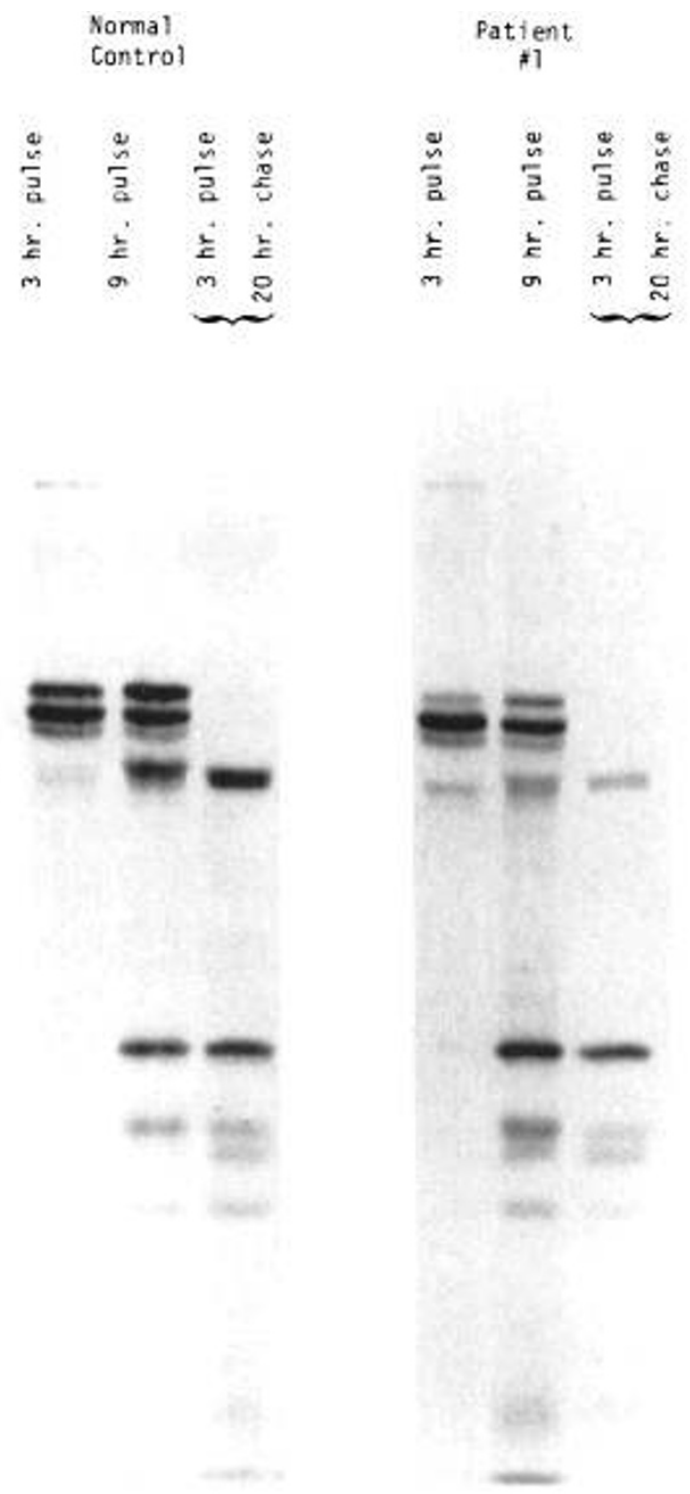

Fig. 5. Electrophoretic analysis of $\beta$-hexosaminidase synthesis in fibroblasts of the two variant patients and a control. Cells were labeled with [ $\left.{ }^{3} \mathrm{H}\right]-$ leucine. immunoprecipitated with antiserum against $\beta$-hexosaminidase $\mathrm{A}$ and electrophoresed on polyacrylamide gel in the presence of $\mathrm{NaDod} \mathrm{SO}_{4}$. Cells were harvested from separate dishes after a $3 \mathrm{~h}$ pulse, a $9 \mathrm{~h}$ pulse and from a third dish after a $3 \mathrm{~h}$ pulse followed by a $20 \mathrm{~h}$ chase. 
precipitated by antiserum against placental hexosaminidase $\mathbf{A}$. After a $3 \mathrm{~h}$ chase, the label was found almost exclusively in polypeptides with molecular weights of $67 \mathrm{~K}$ [previously shown by Hasilik and Neufeld (4) to be an $\alpha$ precursor] and 63K [previously shown to be a $\beta$ precursor]. There was also a trace of a peptide with a weight of $61 \mathrm{~K}$ which is probably a form of the $\beta$ chain. By $9 \mathrm{~h}$, or following a $20 \mathrm{~h}$ chase, the $67 \mathrm{~K} \alpha$ precursor was converted to a $54 \mathrm{~K}$ chain while the $63 \mathrm{~K} \beta$ precursor was processed to a $29 \mathrm{~K}$ chain $(\beta)$ and several smaller fragments. As also shown in Figure 5 , both the precursors, as well as the final forms of the hexosaminidase in the variant individuals appear to be indistinguishable from those of the control fibroblasts.

As shown in Table 5 the ratio of the $\alpha$ chain to the $\beta$ chains was reduced in both individuals 1 and 2 as compared with that found in the control. Although not as yet confirmed, this reduced ratio is that which would be predicted for individuals heterozygous for the "classical" TSD. As shown in Figure 6, these cells also excreted the large molecular weight precursors $(67 \mathrm{~K}$ and $63 \mathrm{~K})$ in a normal fashion in the absence of added $\mathrm{NH}_{3}$ and in increased amounts in the presence of $10 \mathrm{mM} \mathrm{NH}_{4} \mathrm{Cl}$.

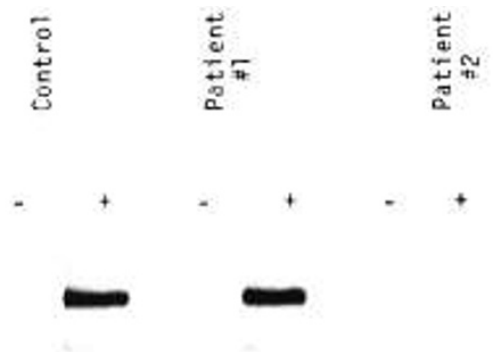

$67 \mathrm{~K}$; a precursor $\}$
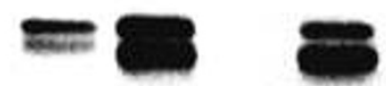

Fig. 6. Electrophoretic analysis of precursors of hexosaminidase excreted in the culture media by fibroblasts. The fibroblasts were labeled with $\left[{ }^{3} \mathrm{H}\right]$-leucine for $3 \mathrm{~h}$ in standard media and in media supplemented with $10 \mathrm{mM} \mathrm{NH}_{4} \mathrm{Cl}$. Following a $20 \mathrm{~h}$ chase in the same media lacking the labeled leucine, the media was immunoprecipitated with antiserum against $\beta$-hexosaminidase $A$, and subjected to polyacrylamide gel electrophoresis in $\mathrm{NaDod} \mathrm{SO}_{4}$. Symbols: -, media not supplemented with $\mathrm{NH}_{4} \mathrm{Cl}$; + media supplemented with $10 \mathrm{mM} \mathrm{NH}_{4} \mathrm{Cl}$.
Table 5. Ratio of $\alpha$ chain to the $\beta$ chains of hexosaminidase

\begin{tabular}{lrrr}
\hline & \multicolumn{2}{c}{ CPM } & Ratio of \\
\cline { 2 - 4 } & $\alpha$ & $\beta$ & $\alpha / \beta$ \\
\hline Cell Extract & & & \\
Patient 1 & 760 & $3180^{\prime}$ & 0.24 \\
Patient 2 & 770 & $2610^{\prime}$ & 0.29 \\
Control & 2590 & $5370^{\prime}$ & 0.48 \\
Media & & & \\
Patient 1 & 350 & 370 & 0.9 \\
Patient 2 & 280 & 380 & 0.7 \\
Control & 1320 & 1160 & 1.1 \\
Media with NH & & & 0.39 \\
Patient 1 & 1810 & 4700 & 0.24 \\
Patient 2 & 470 & 1930 & 0.90 \\
Control & 3090 & 3550 & \\
\hline
\end{tabular}

' In cell extracts $\beta$ includes $29 \mathrm{~K}$ chain plus smaller fragments.

Results of mixing experiments ruled out the presence of an inhibitor of hexosaminidase $A$ in the serum of these patients. Incubation of crude enzyme preparations from control fibroblasts with the patient's serum for periods up to $3 \mathrm{~h}$ at $37^{\circ} \mathrm{C}$ yielded no evidence of an increased rate of inactivation of hexosaminidase A. Results of heat inactivation studies of the fibroblast hexosaminidase at $37^{\circ} \mathrm{C}$ and $52^{\circ} \mathrm{C}$ were indistinguishable from cells of a carrier for TSD. Evidence against increased excretion of hexosaminidase $A$ was provided by the finding that the urinary hexosaminidase $A$ of patient 1 was lower than two controls (62 versus 383 and 366 nmoles of substrate cleaved per h). Moreover, this represented $18 \%$ of the total hexosaminidase activity in patient 1 versus 42 and $58 \%$ for the controls.

\section{DISCUSSION}

We report here the details of a biochemical study of 2 individuals having nonuniform deficiences of hexosaminidase $\mathrm{A}$. While both of these patients lacked detectable hexosaminidase $A$ in serum, their white blood cells and fibroblasts contained, respectively, $15-17 \%$ and $23-26 \%$ of the A form of this enzyme (Table 1). This is in marked contrast to TSD patients where hexosaminidase $\mathbf{A}$ is uniformly absent in all tissues and fluids. In addition, both in vivo and in vitro studies demonstrated that fibroblasts cells from these two individuals metabolize $\mathrm{GM}_{2}$ ganglioside while TSD fibroblasts, analyzed simultaneously, lacked this ability (Tables 2 and 3). These cells also differ from TSD fibroblasts in that they contained cross reactive material for both the $\alpha$ and $\beta$ chains of hexosaminidase (Fig. 5 and 6 and Table 5) whereas TSD fibroblasts are cross reacting material negative for the $\alpha$ chain (4) of this enzyme. Thus, although analysis of hexosaminidase $A$ in serum could not distinguish these variants from TSD patients (Fig. 1), fibroblast studies utilizing both artificial and natural substrates as well as tests utilizing antibodies against hexosaminidase yielded clear and consistent differences.

Differences were also found when these results were compared with previously described persons with atypical hexosaminidase A deficiencies. While many of the hexosaminidase A variants, reported to date, had partial or marked deficiencies of hexosaminidase $\mathrm{A}$, the decreases appeared to be generalized, i.e., more or less uniformly decreased in each of the tissues and/or fluids examined $(3,5,7,13)$. Moreover, in those variants with clinical disease, i.e, $\mathrm{GM}_{2}$ gangliosidosis Type II, Sandhoff and A B variant, the loss of $\mathrm{GM}_{2}$ cleaving activity in fibroblasts, when tested, has been more severe than that found in these two patients $(10,12)$.

Of the variants previously described, the results given here most closely resemble those found in a 19-year-old healthy mother of a TSD child described by Vidgoff et al. $(17,18)$. As with our patients, this individual was characterized by an absence of serum hexosaminidase $A$ and preservation of both hexosaminidase $A$ and $\mathrm{GM}_{2}$ cleaving activity in fibroblasts (17). 
At the present time, the defect responsible for the alterations in these two patients is unclear. Indeed, it is not established that the basic defect is identical in the two individuals. The data suggest that both of these patients are probably heterozygous for the classical TSD mutation. In addition these patients must also suffer from a second abnormality (genetic or physiologic) which is responsible for the nonuniform distribution of the remaining hexosaminidase $A$. If this interpretation is correct, the second phenomenon would result in a relative preservation of activity against both $\mathrm{GM}_{2}$ ganglioside and 4-methylumbelliferyl-N-acetylglucosaminide in fibroblasts but in an absence of the same activity in serum.

Data suggesting that these abnormalities were not due to defective synthesis or processing of precursor forms of the enzyme was provided by the results of the pulse experiments. As with control fibroblasts, the hexosaminidase was labeled in precursor forms, i.e., an $\alpha$ chain of $67 \mathrm{~K}$ and a $\beta$ chain of $63 \mathrm{~K}$. With time, the $67 \mathrm{~K}$ $\alpha$ chain was processed to $54 \mathrm{~K}$ form while the $\beta$ chain was processed to a final subunit of $29 \mathrm{~K}$ (Fig. 5). Evidence that cultured fibroblasts from these patients retained their ability to excrete the enzyme or its precursor forms was shown by incubating the fibroblasts in the presence of $\mathrm{NH}_{4}{ }^{+}$. Under these conditions, secretion of the $\alpha$ and $\beta$ chain precursors by the patient's and control's fibroblasts was enormously enhanced (Fig. 6).

At the present time, it is difficult to state with certainty, the clinical significance of the biochemical findings described in these patients. The ability of these cells to cleave $\mathbf{G M}_{2}$ ganglioside in both in vitro and in vivo assays strongly suggests that both patients will escape any form of $\mathrm{GM}_{2}$ gangliosidosis. We are unaware of any individual having comparative $\mathrm{GM}_{2}$ ganglioside galactosaminidase activity who suffers from any form of $\mathrm{GM}_{2}$ gangliosidosis. Moreover, the \% of hexosaminidase A $(23-26 \%)$ in the fibroblasts of these persons are higher than the values reported for fibroblasts of most, if not all, of atypical $\mathrm{GM}_{2}$ gangliosidosis patients described to date $(3,5,7,13)$.

Direct support for the above conclusion is provided by the fact that patient 2 is presently 43-years-old and in excellent health (9). Detailed clinical examinations of patient 1 have also failed to demonstrate any clinical abnormalities; however, it must be noted that he is presently less than 1-year-old. Indeed, this infant only came to medical attention as a result of the finding that both of his parents had hexosaminidase $A$ values that fell within the carrier range for TSD. Cultured amniotic fluid cells obtained from his mother prior to his birth yielded hexosaminidase $A$ values of $26 \%$ (range $25-31 \%$ ) by the heat inactivation method (Fig. 4). An electrophoretic analysis of these cells demonstrated the presence of a strong A band indistinguishable from that seen in cells from TSD carriers. In contrast, cultured amniotic fluid cells studied in this laboratory from five fetuses affected with TSD had an average of $6 \%$ hexosaminidase with a range of $3-7.5 \%$ and no detectable hexosaminidase A by electrophoresis. Indeed, failure to detect hexosaminidase in the cord blood and multiple serum samples was the first evidence that this patient had an unusual form of hexosaminidase $A$. Of clinical importance is the fact that serum hexosaminidase A values will not always reflect the status of either the levels of the enzyme in other tissues or, in a few rare cases, the clinical status of the patient. Moreover when amniotic fluid cell and serum results differ, they can (and in this case did) cause severe medical and diagnostic difficulties. Hopefully, studies of this type will help to eliminate this problem and lead to a better understanding of the basic defect in these variant individuals.

\section{REFERENCES AND NOTES}

1. Bremer, E. G., Gross, S. K. and McCluer, R. H.: Quantitative analysis of monosialo-gangliosides by high performance liquid chromatography of their perbenzoyl derivatives. J. Lip. Res., 20: 1028 (1979).

2. Folch-Pi, J., Lees, M., and Sloane-Stanley, G. H.: A simple method for the isolation and purification of total lipids from animal tissues. J. Biol. Chem.. 226: 497 (1957).

3. Grabowski, G. A., Willner, J. P., Bender, A., Gordon, R. E. and Desnick, R. J.: Chronic $\beta$-hexosaminidase $A$ deficiency-clinical and biochemical studies of a new neuromuscular disease. Pediatr., Res., 14: 632 (1980).

4. Hasilik, A. and Neufeld, E. F.: Biosynthesis of lysosomal enzymes in fibroblasts. Synthesis as precursors of higher molecular weights. J. Biol. Chem.. 255: 4937 (1980).

5. Johnson, W. G., Cohen, C. S., Miranda, A. F., Waran, S. P. and Chutorian, A. $\mathbf{M}$ : $\beta$-locus hexosaminidase genetic compound with juvenile gangliosidosis phenotype: Clinical. genetic and biochemical studies. Am. J. Hum. Genet., 32: 508 (1980).

6. Kaback, M. M.: Thermal fractionation of serum hexosaminidase: Applications to heterozygote detection and diagnosis of Tay-Sachs disease. In: V. Ginsburg and E. Neufeld: Methods of Enzymology, p. 862 (Academic Press, New York, New York, 1973).

7. Kaback, M., Miles, J., Yaffe, M., Itabashi, H., Mclntyre, H., Goldberg, M. and Mohandas, T.: Hexosaminidase A (Hex A) deficiency in early adulthood: A new type of $\mathrm{GM}_{2}$ gangliosidosis. Am. J. Hum. Genet., 30: 31 A (1978).

8. Kaback, M. M., Nathan, T. J., and Greenwald, S.: Tay Sachs disease: heterozygote screening and prenatal diagnosis-U.S. experience and world perspective. In: M. M. Kaback: Tay-Sachs Disease: Screening and Prevention, p 13. (Alan, R., Liss, Inc., New York, New York, 1977).

9. Kelly, T. E., Reynolds, L. W., and O'Brien, J. S.: Segregation within a family of two mutant alleles for hexosaminidase A. Clin. Genet.. 9: 540 (1976).

10. Kolodny, E. H., Raghavan, S. S., Ellison, P. H., Lyerla. T. A., and Bremer, E. G.:

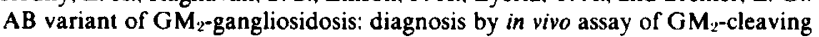
activity in cultured skin fibroblasts, Abstract \#13, Ninth meeting of the Child Neurology Society, Savannah, Georgia, (1980).

11. Lie, K. K., Thomas, G. H., Taylor, H. A. and Sensenbrenner, J. A.: Analysis of $\mathrm{N}$-acetyl- $\beta$-D-glucosaminidase in mucolipidosis II (I-cell disease). Clin. Chim. Acta, 45: 243 (1973).

12. O'Brien, J. S., Norden, A. G. W., Miller, A. L., Frost, R. G. and Kelly, T. E.: Ganglioside $\mathrm{GM}_{2}$ N-acetyl- $\beta$-D-galactosaminidase and asialo $\mathrm{GM}_{2}\left(\mathrm{GA}_{2}\right) \mathbf{N}$ acetyl- $\beta$-D-galactosaminidase; studies in human skin fibroblasts. Clin. Genet., 11: 171 (1977).

13. Navon, R., Geiger, B., Yoseph, Y. B. and Rattazzi, M. C.: Low levels of $\beta$ hexosaminidase $A$ in healthy individuals with apparent deficiency of this enzyme. Am. J. Hum. Genet., 28: 339 (1976).

14. Rattazzi, M. C. and Davidson, R. G.: Prenatal detection of Tay-Sachs disease. In: A Dorfman: Antenatal Diagnosis, p. 207. (The University of Chicago Press. Chicago, IL, 1972).

15. Taylor, H. A., Thomas, G. H., Miller, C. S., Kelly, T. E., and Siggers, D. Mucolipidosis III (pseudo-Hurler polydystrophy): Cytological and ultrastructural observations of cultured fibroblast cells. Clin. Genet.. 4: 3888 (1973).

16. Ullman, M. D. and McCluer, R. H.: Quantitative analysis of plasma neutral glycosphingo lipids by high performance liquid chromatography of their perbenzoyl derivatives. J. Lip. Res., 18: 371 (1977).

17. Vidgoff, J., Buist, N. R. M., Miller, A., Tennant, L. and O'Brien, J. S.: Nonuniform distribution of hexosaminidase A. Am. J. Hum. Genet., 26: 89A (1974).

18. Vidgoff, J., Buist, N. R. M. and O'Brien, J. S.: Absence of $\beta$-N-acetyl-Dhexosaminidase A activity in a healthy woman. Am. J. Hum. Genet., 25: 372 (1973).

19. Chemetron, Gustavo Modena, 24 Milan. Italy.

20. Requests for reprints should be addressed to: George H. Thomas, Ph.D., The John F. Kennedy Institute, 707 N. Broadway, Baltimore, MD 21205 (USA).

21. This study was supported by NIH grant HD-10981.

22. The authors thank patient 2 and the family of patient 1 for their cooperation during these studies.

23. Received for publication April 2. 1981

24. Accepted for publication June 19, 1981. 